\title{
Exploring Lincoln
}


This page intentionally left blank 


\section{The North's Civil War}

Andrew L. Slap, series editor 


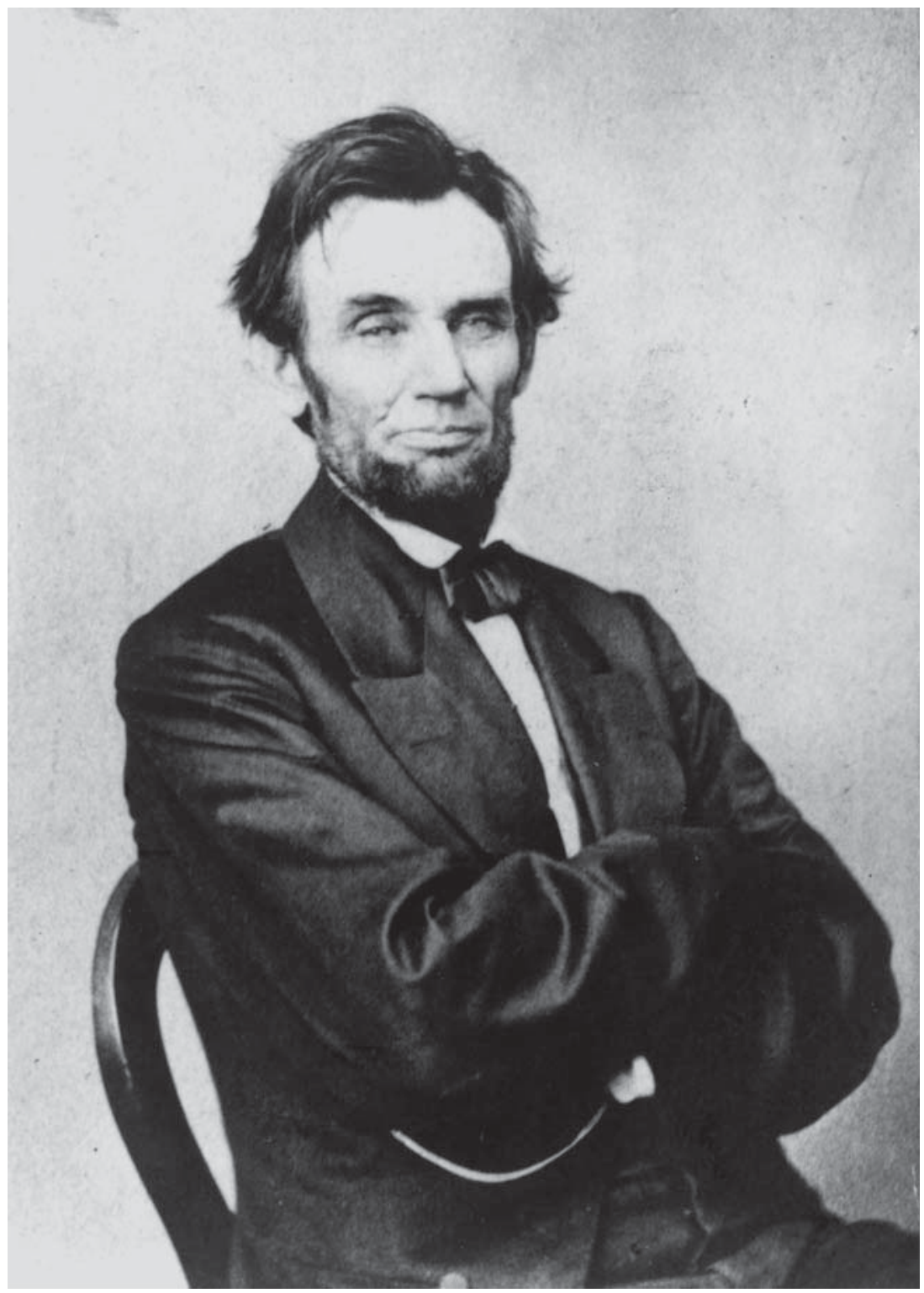


A Lincoln Forum Book

\title{
Exploring Lincoln
}

\section{Great Historians Reappraise Our Greatest President}

\author{
EDITED BY
}

Harold Holzer, Craig L. Symonds,

$$
\text { AND }
$$

Frank J. Williams 
Frontispiece: Abraham Lincoln, ca. 1863, photograph by Lewis E. Walker, Washington, D.C. (Library of Congress)

Copyright (C) 2015 Fordham University Press

All rights reserved. No part of this publication may be reproduced, stored in a retrieval system, or transmitted in any form or by any means-electronic, mechanical, photocopy, recording, or any other-except for brief quotations in printed reviews, without the prior permission of the publisher.

Fordham University Press has no responsibility for the persistence or accuracy of URLs for external or third-party Internet websites referred to in this publication and does not guarantee that any content on such websites is, or will remain, accurate or appropriate.

Fordham University Press also publishes its books in a variety of electronic formats. Some content that appears in print may not be available in electronic books.

Visit us online at www.fordhampress.com.

Library of Congress Cataloging-in-Publication Data

Exploring Lincoln : great historians reappraise our greatest president / edited by Harold Holzer, Craig L. Symonds, and Frank J. Williams. First edition.

pages cm. - (The North's Civil War)

Includes bibliographical references and index. ISBN 978-o-8232-6562-6 (cloth : alk. paper) ISBN 978-o-8232-6563-3 (pbk. : alk. paper)

1. Lincoln, Abraham, 1809-1865-Influence. 2. United States-Politics and government-1861-1865. 3. Political leadership-United States-

History-19th century. 4. Presidents-United States-Biography.

I. Holzer, Harold, editor, author. II. Symonds, Craig L., editor, author.

III. Williams, Frank J., editor, author.

$$
\begin{gathered}
\mathrm{E}_{457 . \mathrm{E} 96 \quad 2015} \\
973.7092-\mathrm{dc} 23 \\
2014033578
\end{gathered}
$$

Printed in the United States of America

$\begin{array}{llllllll}17 & 16 & 15 & 5 & 4 & 3 & 2 & 1\end{array}$

First edition 